UNIO - EU Law Journal. Vol. 6, No. 2, July 2020, pp 57-65.

®2020 Centre of Studies in European Union Law

School of Law - University of Minho

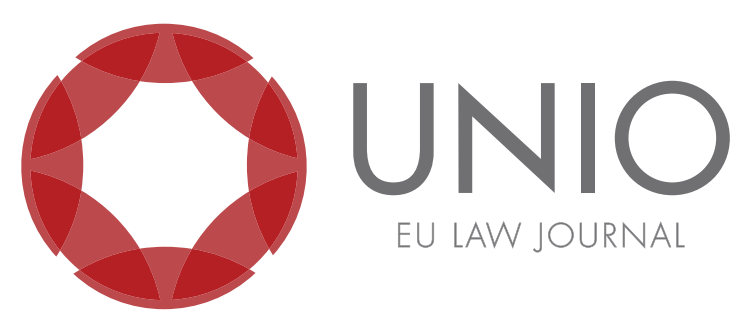

\title{
Locally decentralised responses to the European recovery: exploring the role of the Euratom Treaty and the ESM
}

\author{
Alfonso Iozzo* \\ Fabio Masini** \\ Antonio Padoa-Schioppa***
}

ABSTRACT: The pandemic stressed the key role of sustainable consumption and production patterns and highlighted the role of local systems as key actors of a recovery aiming at enhanced resilience to endogenous and exogenous shocks. Although the Recovery Plan marked a radical shift in the attitude of the EU towards crisis management and allowed for an unprecedented joint financial effort, it might not be enough for tackling the challenges ahead. In this paper we suggest that two instruments should be further explored for this purpose: the Euratom Treaty and the European Stability Mechanism.

KEYWORDS: European recovery - local systems - Euratom Treaty - European Stability Mechanism.

\footnotetext{
* Alfonso Iozzo is Vice-President of Triffin International and former Chairman of Cassa Depositi e Prestiti. ${ }^{* *}$ Fabio Masini is Jean Monnet Chair on European Economic Governance at Roma Tre University.

*** Antonio Padoa-Schioppa is Professor Emeritus at the University of Milan and former President of Centro Studi sul Federalismo.
} 


\section{Introduction}

The pandemic changed in depth the perception of the European public opinion about the counter-cyclical and growth-enhancing instruments available at the EU level. In a few months, we unexpectedly discovered that, notwithstanding still critical issues concerning an ineffective collective decision-making system, Europe was able to agree on a massive Recovery Plan, based on jointly issued obligations and own resources (still to be agreed upon).

While this was announced as a temporary and exceptional measure, the full recovery of the European economy requires greater investment in industries and projects that allow for the full sustainability (in environmental, social, and financial terms) of the EU's future production and consumption patterns; and a robust increase in the resilience of the European society to exogenous and endogenous shocks.

Building on two previous notes, ${ }^{1}$ we suggest that two instruments should be further explored for this purpose: the Euratom Treaty and the European Stability Mechanism ("ESM"). The former may seem to be a mere ghost of the past, and some readers might be surprised to discover that it is still alive; the latter is a mechanism that reminds one of a doom and undue intromission of the troika into the domestic affairs of Greece, imposing a strict austerity stance.

Nevertheless, they might prove to be particularly apt for the forthcoming needs of the European economy, under at least two perspectives. The first is the urge to finance the Green Deal, as a major priority set by the European Commission for the long-term competitiveness and sustainability of the European economy at the global level. The second is to guarantee funding for crucial local infrastructure.

The Euratom Treaty, after being "frozen" within the Lisbon Treaty, is a potentially powerful instrument only waiting for the political will to emerge for its implementation on a large scale. The ESM is in search for a new identity, after a phase as State rescue fund.

In order to explain our suggestion that is meant to complement the current financial effort of the European Union and its instruments, we shall devote the first section to recall some crucial needs of the European economy, as emerged before and reinforced after - the pandemic; the second section is devoted to the role that might be played by the Euratom Treaty; the third to the ESM.

\section{A bottom-up economy for the future}

Two aspects will probably stand out for their impact on the way the European economy and society shall adapt to the transformation required (and induced) by the recent global evolutions: climate change and the pandemic shock.

The first concerns the need to provide more sustainable consumption and production patterns, thanks to: investments in climate-neutral technologies; a circular economy with integrated waste recycling mechanisms; and a transition towards clean and more efficient energies. These are the key features of the Green Deal. In order to push on this, a massive commitment by both private actors and public authorities

\footnotetext{
${ }^{1}$ Alfonso Iozzo and Fabio Masini, "A Green Deal for European cities. Rethinking the role of the European stability mechanism”, Centro Studi sul Federalismo Policy Paper, no. 45 (May 2020); Alfonso Iozzo and Antonio Padoa-Schioppa, "The Green Deal and Euratom", Centro Studi sul Federalismo Comment, v. 167, no. 24 (February 2020).
} 
is required, providing an investment-friendly framework and resources that may trigger a long-lasting change.

The second concerns the need to rethink social, economic, political, and territorial planning in a way that allows a prompt, more efficient, decentralised - but also coordinated - response to exogenous shocks, that transcends current (State-centered) administrative and policy boundaries. This raises two related issues: the need to pay greater attention to the concept of the "smallest surviving unit", that might sit astride existing juridical administrations; and a reflection on what kind of infrastructure is required to make such units more resilient and reactive.

On this latter point, it is key to finance crucial local infrastructure that allow such local areas to effectively react to exogenous shocks and challenges; this implies competing on financial markets against the destabilising (but often high-yield) component of market-induced instability due to short-termism (and the extremely variable demand for liquidity required to cover short-term obligations in times of crisis), redirecting resources towards long-term assets. As the public debate suggests both in the $\mathrm{USA}^{2}$ and the $\mathrm{EU}^{3}$, major cities are already pushing hard in this direction, calling for a reshaping of the role, functions and competences of local communities.

The concept of "smallest surviving unit" as the minimum dimension of communities allowing for the survival of its members - once the "tribe", later the "polis", then the "nation-State", and lately the "whole planet" - was profoundly shaken by the pandemic. In order to face a global problem, we re-discovered that the Nation-State is the only legal framework that can pass and enforce containment laws, and provide public goods that individuals require for their survival (latu sensu).

At the same time, we discovered that all Nation-States, whatever their dimension, face similar domestic, sub-national issues concerning the optimum/most efficient degree of decentralisation of some crucial activities, such as sanitary measures, social control, provision of assistance to those in need, etc. We also found that in the absence of a coordinated supranational response to a supranational issue, the most likely outcome is an increasing gap between individuals, regions, States, continents; a potentially disrupting perspective for the future.

The globalisation and dematerialisation of some economic activity in the last few decades have overshadowed the crucial role of communities: in bridging market dynamics, and the role of collective decision-making of public authorities; ${ }^{4}$ and in their key role of community control and absorption of the negative effects of globalisation. This suggests that a truer - and constitutionally recognised - multilayered system of (independent and coordinated) governments ${ }^{5}$ might be able to cope more efficiently with the multilayered nature of the problems we face. ${ }^{6}$

As a consequence of the current state-centered approach to public choice, two layers of government remain underfinanced and underprovided for in terms

\footnotetext{
${ }^{2}$ World Urban Forum, "Making cities resilient 2030 (MCR 2030) - initial proposal", UNDDR, 2020, https://www.unisdr.org/campaign/resilientcities/home/article/making-cities-resilient-2030mcr2030-initial-proposal.

3 "Letter to the President of the European Commission", Matúš Vallo et al., February 11, 2020, https://budapest.hu/sites/english/Lapok/2020/eu-lobby.aspx.

${ }^{4}$ Raghuram Rajan, The third pillar. How markets and the State leave the community behind (London: William Collins, 2019).

${ }^{5}$ In the USA too, there is an increasing awareness on the need to return to a more decentralized, genuinely multilayered, federal structure of the State.

${ }^{6}$ Lionel Robbins, Economic planning and international order (London: Macmillan, 1937).
} 
of (collective) public goods: the community level, and the supranational level. For this reason, we suggest that an existing supranational financial instrument like the ESM, suitably modified, might serve as a fund for supporting the lower, communitylevel, long-term public investments (as argued also by Sassoli ${ }^{\top}$ ), solving the twofold problem related to the under-provision of both supranational and sub-national public goods.

This would allow both a joint, strategic view of the required investment policies, accompanied by collective financing, monitoring and control; and a bottomup design of community-specific infrastructure, that would ensure full democratic involvement ${ }^{8}$.

The "smallest surviving units" can be defined (in the 2020 world) as local systems large enough to allow for the smooth functioning of the underlying (internal) community ${ }^{9}$ and small enough to be identifiable from the rest of the greater (external) community, proving an optimum balance between agglomeration economies and diseconomies. Each of them can be visualised as the spider's web system of public goods and services (utilities, transports, social and cultural centers, etc.) needed for everyday life to be operational and resilient to shocks. ${ }^{10}$

In many cases, these are metropolitan areas, or major coordinated local systems of highly interconnected territories. Of course, "surviving units" do not imply selfsufficiency: we are living in a complex and intertwined world that cannot survive in the long term without major connecting infrastructure. But they are able, in cases of shorter-term perspectives driven by emergencies, to react efficiently to exogenous shocks, absorbing their negative impact.

When we speak of community-based infrastructure, we do not just mean traditional infrastructure such as roads, bridges, airports; but broadband, energy production and distribution, waste recycling, innovative and flexible hospitalisation and health management systems, research laboratories and networks, interconnected logistics, social mobility, new ways to design the relationship between major cities and their territories, re-engineering the welfare state to cope with an ageing population, etc. Most of this (material and immaterial) infrastructure requires enormous capital and a governing system involving the active participation of a number of private and public actors, on multiple levels.

Financing both the Green Deal and local infrastructure on the Recovery Plan and Multiannual Financial Framework alone is insufficient, if we are to acknowledge and agree on the amount of resources expected by studies of the European Commission and others. For this reason, we believe that the Euratom Treaty and a modified EMS should be carefully considered.

\section{A new Euratom for the Green Deal}

Environmental challenges require very demanding but certainly feasible economic and fiscal policy choices, if (and only if) adopted within the Union

\footnotetext{
${ }^{7}$ David Sassoli, "Aiuti da Bruxelles arriveranno, il punto è che l'Italia sappia spenderli", Interview by Paolo Valentino, Corriere della Sera, April 23, 2020, https://www.corriere.it/esteri/20_aprile_22/ coronavirus-sassoli-corriere-aiuti-bruxelles-arriveranno-punto-che-l-italia-sappia-spenderli280088a2-84c8-11ea-8d8e-1dff96ef3536.shtml.

${ }^{8}$ Francesco Rossolillo, Città territorio istituzioni (Napoli: Guida, 1983), 47.

${ }^{9}$ Adriano Olivetti, L'ordine politico delle comunità (Ivrea: Nuove Edizioni, 1945).

${ }^{10}$ World Urban Forum, "Making cities resilient".
} 
framework. With regard to climate risk, several lines of action are being designed, also in relation to the commitment of the Commission and the European Parliament.

The Commission has indicated the need to mobilise a volume of resources in the order of 1.000 billion over ten years, a figure that could be achieved with a public contribution from the Union in the order of 100 billion euros per year, variously structured, which would act as a guarantee for a multiplier of funding. ${ }^{11}$ Careful consideration has been given to the costs of establishing a carbon tax, ${ }^{12}$ limited at the outset only to the borders outside Europe.

The European Parliament has endorsed the objective of the European Green Deal, ${ }^{13}$ which the new Commission under the leadership of Ursula von der Leyen has placed at the heart of its five-year program, ${ }^{14}$ with the activation of a first Transition Fund (Just Transition Fund) of 100 billion euros, to which, as has been said, another 900 billion euros would be added in a decade from various channels in the Union budget. Calculations by the European Court of Auditors and other authoritative experts ${ }^{15}$ nevertheless indicate a much higher figure, about 3 trillion euros in a decade, necessary to neutralise the climate risk by 2050 .

Recent suggestions ${ }^{16}$ proposed the establishment of a European Bank for Climate and Biodiversity (for a financial commitment of 100 billion euros each year for a decade) to support the ecological transition in Europe and Africa (considered as strategic to European interests). The Commission's President suggested that the European Investment Bank ("EIB") might be changed towards this purpose; and other observers and experts have proposed the creation of a European Carbon Central Bank, ${ }^{17}$ as a pathway to tackle low political credibility of the European Emissions Trading Scheme among investors.

In the last few months, though, the path emerged as more viable for this compared to other alternatives constituted by a revision of the Treaties and enhanced cooperation - is that of a treaty outside the European Treaties, to be concluded between the countries available in the form of an intergovernmental pact.

Another approach that might be followed is anchored more directly to the Union's institutional framework, assuming the use of the existing Treaties, with the necessary involvement of the European Parliament, the Commission and the two Councils.

\footnotetext{
11 "Not all member states will benefit from the European Green Deal", EurActiv, January 16, 2020, https://www.eceee.org/all-news/news/ not-all-member-states-will-benefit-from-the-europeangreen-deal/.

${ }^{12}$ Alberto Majocchi, European budget and sustainable growth. The role of a carbon tax (Torino: Centro Studi Sul Federalismo, 2018), http://www.csfederalismo.it/it/pubblicazioni/volumi/collana-federalism/1393european-budget-and-sustainable-growth.

${ }^{13}$ European Parliament, Resolution of 15 January 2020 on the European Green Deal (2019/2956(RSP), P9_TA(2020)0005, https://www.europarl.europa.eu/doceo/document/TA-9-2020-0005_EN.pdf.

${ }^{14}$ Ursula von der Leyen, "A Union that strives for more. My agenda for Europe”, Political guidelines for the next European Commission 2019-2024, https://ec.europa.eu/commission/sites/betapolitical/files/political-guidelines-next-commission_en.pdf.

${ }^{15}$ Roberto Palea, "Il valore strategico del Green Deal europeo", Comment no. 164, January 8, 2020 http://www.csfederalismo.it/it/pubblicazioni/commenti/1459-il-valore-strategico-del-green-dealeuropeo.

${ }^{16}$ See the sites: "Climate-Finance Pact", available at: https:/ /www.federalists.eu/fileadmin/files_uef/ Events/2019/We_are_Europe_2019/Climate_Change-Finance_Pact.pdf and "PETITION - Let's stop Climate-killers from paralysing the European Commission", available at: https://www.pacteclimat.eu/en/.

17 "Why a European Carbon Central Bank", MCC Press Release, Berlin, November 6, 2014, https:// www.stiftung-mercator.de/en/press-releases/nachricht/why-a-european-carbon-central-bank/.
} 
After the Treaty of the Czech Republic ("European Coal and Steel Community") was incorporated into the two Treaties on the European Union ("TEU") and on the Functioning of the European Union ("TFEU") - updated after the approval of the Lisbon Treaties - the structure for future EU energy and environment policies could be based on the Euratom Treaty (i.e. the "European Atomic Energy Community" "CEEA") in the consolidated version still in force.

To this end, it would be necessary to extend the competences of the TEU, TFEU and Euratom Treaties to other energy sources, the discipline of which is now unachievable in the planning of the Union's future economic and environmental policies. The latter Treaty could be renamed the European Energy and Environment Community ("ECEA").

One legal question that arises in this respect concerns the procedure that would be necessary to achieve this objective. Given that an amendment of the Euratom Treaty would in any case be necessary to this end, the question is this: is it possible to use the procedure laid down in the second paragraph of Article 48(3) of the TEU, which allows the Treaties to be amended by a simple majority of the Council and without the need to convene a Convention, subject to approval by the European Parliament? Or, alternatively, would it also be possible to use the procedure laid down in Article 48.6 of the TEU, which governs the simplified procedure provided for in Part Three of the TEU on the Union's internal policies and actions?

The answer would seem clear, in the sense of the admissibility of the first procedure but not of the second, since Article 106a of the Euratom Treaty (2012) expressly provides for the possible application of Article 48(2) to (5) of the TEU, but not of paragraph 6 , which would seem to exclude the possibility of using the simplified procedure.

The Euratom Treaty, in its consolidated version of 2012, also provides, in Article 206, for the adoption of the procedure of Article 48(2) to (5) for Agreements with one or more States or international organisations which require an amendment of the Euratom Treaty in order to establish an association characterised by reciprocal rights and obligations.

The use of the Euratom Treaty for EU policies on renewable energy and the environment would have the great advantage of providing a ready-made legal framework fully consistent with the existing institutional structure. Very important would be the rules of the Euratom Treaty on the establishment of one or more Agencies empowered to pursue the relevant policies (Articles 52-56 of the Euratom Treaty, 2012) as well as the rules on financial provisions in Articles 171-172, including the right to issue loans on the capital market.

The latter element is of great importance, as it would enable additional funding to be activated for the development of new technologies, which require substantial resources that can only be partially activated with private capital. It has now been demonstrated that for investments in structures that take a long time and do not guarantee returns in the short term, only public resources can make up for it effectively: as the American model has also shown in the remote and recent past.

It should be added that, without prejudice to the need to supplement the European Union's powers in the future by reforming the Treaties by granting autonomous fiscal power to the European Parliament in co-decision with the Council, the current legislation already allows the adoption of provisions of a fiscal nature, either through special or ordinary legislative procedures (Article 192.2 of the 
TFEU) or through enhanced cooperation or a specific intergovernmental agreement, as recently confirmed - as regards the latter two cases - by the European Court of Justice. ${ }^{18}$

\section{Contextualizing the nature and scope of the ESM}

The ESM was established in 2012 to tackle potentially destabilising financial imbalances in any of the Euro-area members, more promptly and effectively than the European Financial Stability Facility (hence "EFSF"), by furnishing them with credit when market conditions unfavorable. The fund has an authorised capital of 704.8 billion euros, of which only 80 billion are actually paid-up, and has a lending capacity capped at 500 billion euros.

As a joint enterprise of the Euro-area Member States, loans from the ESM represent a joint obligation in case of sovereign default. They are, therefore, a collective liability. Being a permanent financial institution under public international law that (after the IMF) can claim a preferred creditor status, the ESM can also (and usually does) issue bonds on the market that, being backed collectively, have a 'triple A' rating (Fitch).

According to its extra-ordinary mission, to tackle cases of severe financial distress, the ESM provides liquidity, conditional on a wide-ranging program of debt restructuring and reduction. In fact, such strict conditionality proved socially and politically destabilising only in the Greek case (out of five applying countries, the others - Ireland, Portugal, Cyprus and Spain - having used the ESM's resources successfully, the last one to strengthen its banking system). In the Greek case, more than three hundred billion euros were provided (in three rounds of negotiations, that started under the EFSF) to stabilise the macroeconomic figures of a country that had experienced deficits of up to 15\% of GDP for some years. Greece ended its ESM program after eight years (EFSF plus ESM), in August 2018.

Acknowledging the imminent need for the ESM to go beyond its original mission, in December 2017, the European Commission published a roadmap, ${ }^{19}$ setting the target for the transformation of the ESM into a proper European Monetary Fund ("EMF"). ${ }^{20}$ This proposal had a threefold aim: a) to increase the accountability and legitimacy of its decision-making mechanism and procedures, bringing it within the scope of the EU legal system; b) to facilitate the implementation of the Four/Five Presidents' Reports of 2012 and 2015 on the completion of the economic and monetary union and; c) to anticipate the extension of the Euro-area to the whole EU27. In the meantime, the European Council decided to use the ESM as a backstop for the Single Resolution Fund within the EU's banking union, a reform currently under scrutiny by the Member States that should be adopted by the end of 2020 .

These changes were all decided in the pre-Covid-19 era, and still aimed at better safeguarding the financial stability of Euro-area Member States. The current, generalised and symmetric shock delivered by the coronavirus pandemic offers an opportunity to accelerate and widen the nature of this transformation. The recent decision to allow access to the ESM to finance improvements to health systems is a step in this direction.

\footnotetext{
${ }^{18}$ Cases C-209/13 and C-370/12.

${ }^{19}$ European Commission, Further steps towards completing Europe's Economic and Monetary Union: a roadmap, $\operatorname{COM(2017)~} 821$ final, Brussels, December 06, 2017.

${ }^{20}$ European Commission, Proposal for a Council Regulation on the establishment of the European Monetary Fund, COM(2017) 827 final, Brussels, December 06, 2017.
} 
We have already stressed that most services/infrastructure can be best organised, managed and monitored at the level of major local areas: health-care systems and the welfare state, public transport, cultural socialisation, innovative solutions for an ageing population, energy production and distribution, etc. We suggest that such investments (by large municipalities or consortia of local authorities) should be implemented through the emission of Sustainable Bonds by the ESM. The ESM can be flexible and reactive; and it can be adjusted to serve the agenda set by the European Commission and its six priorities, therefore assuring strategic unity in providing funds for investments.

The ESM might therefore be transformed into a lending facility for the support of long-term investments, following the model of national financial institutions like Deposit and Loans Funds (Cassa Depositi e Prestiti in Italy, Caisse des dépôts et consignations in France, Crédit Communale de Belgique, etc), and thus act as the EU's arm for executing public policy mandates. Sustainable Bonds should have a long maturity and might be purchased by the ECB (as is presently the case for most of the ESM's debt).

For this purpose, the ESM can (currently) count on a paid-up capital of 80 billion euros, with a lending capacity of 500 billion euros. This means that a leverage of six can be seen as a reasonable proxy for its enhanced lending capacity. Given that the total authorised capital of the ESM is 704.8 billion euros, once all this capital is paid (let's imagine a schedule of ten years to reach the target), the credit capacity of the ESM might hit 4.000 billion euros. This might be a sufficient amount, around 3\% of the EU27 GDP (about 13.500 billion euros in 2018) for ten years.

The ESM should also operate as a re-insurer to the system of national public investment banks (the Cassa Depositi e Prestiti, etc) to finance smaller local initiatives, such as the modernisation of local transport or building schools, hospitals, waste recycling facilities and the like in small cities.

The only conditionality required in this initiative should concern the use of resources to finance investments that prove to be sustainable in terms of: financial soundness (ability to generate cash-flows that guarantee the payment of debt instalments), social cohesion, intergenerational opportunities, environmental protection, and technological and energy innovation. The eligibility criteria, selection and monitoring of such initiatives should be set by the European Commission, acting according to the strategic plan for a Green Deal.

This specific role for the EMS, providing collective public goods at the subnational, community, level that is usually neglected, might also have a positive impact on European citizens' perception of the overall role of European institutions.

\section{Concluding remarks}

The pandemic-related emergency stressed the urge to create a more sustainable environment and the relevance of local authorities in responding to social challenges and the provision of essential public goods. A new, bottom-up, process of local democracy should be built, constitutionally recognised, legitimised, and made enforceable; a process that allows for locally decentralised responses and strategic unity.

Such strategic unity, pending the implementation of a more democratic collective decision-making process in Europe, can be provided by the six priorities set by the new European Commission for its mandate. In particular, the Green Deal: meant to remind us of the New Deal launched by Roosevelt in the Thirties to restart the economy after the Great Depression, the Green Deal aims to foster 
innovation, global competition, the transformation of production and the building of infrastructure that can cope with future sustainability challenges.

From this point of view, we suggest that two instruments should be further explored and exploited: the Euratom Treaty, which may represent an efficient mechanism for dealing with the macro-dynamics and projects concerning the Green Deal, and the ESM, transformed into a Sustainable Fund, helping finance long-term local investments in infrastructure with Sustainable Bonds.

Recourse to these and other appropriate strategies requires, of course, an impetus which can only come from politics at European level: hence the importance of the process which started with the new European Parliament legislature, the new Commission, with the pandemic, and with the forthcoming Conference on the Future of Europe, that might provide further bottom-up legitimation to this process. 